\title{
English Puritanism and Festive Custom
}

\author{
ALEXANDRA F. JOHNSTON
}

$\mathrm{O}_{\mathrm{n}}$ February 1, 1621, John Marten, Vicar of the parish church of St John the Baptist, Windsor sent a petition to an official of the ecclesiastical courts, one Master Jones, complaining against the activities of his churchwarden:

Master Iones, though as yett I am vnknowne to you yett I am bold to entreate you to be my proctour \& to put into the Court, by way of Articles against Thomas Hall Churchwarden of New-Windsor Inkeeper. these particulars following.

1. That the said Thomas Hall is a common swearer blasphemer \& curser, not onelie in priuate houses but also in the open streetes to the great offence \& griefe of many.

2. That the said Thomas Hall vsuallie receiueth the holie sacrament of the Lords supper but once in the yeare.

3. That the said Thomas hath maintayned playing at pigeon holes, many Saterdayes together both in the last yeare $1619, \&$ also in this year 1620 in the tyme of Euening prayer neare to the Church yard wall. ${ }^{1}$

4. That the said Thomas vpon Easter munday last in the tyme of Euening prayer was present at a play with many others, at the signe of the Georg in Windsor, so that through his example few persons were present at diuine seruice

5. That the said Thomas, vpon the feast of the Ascension of Christ, last past, did procure bricklayers to mend vp the Churchyard wall \& suffered Carpenters to worke that whole day in the markett place; oftens accompanying them ./.

6. That the said Thomas, at the celebration of the holie sacrament of the Lords supper did with a lowde voyce, expostulate, chyde \& wrangle with one Robert Michener a poore labouring man \& with Clement his wife: adding moreouer these words, except you pay your $2 \mathrm{~d}$ come no more here, \& also adding this threatning I will talke with you in another place: as that not onelie the said Robert \& Clement his wife, were much greiued, being readie to receiue the holie sacrament, but also the minister \& diuerse Communicants, were greatlie disturbed

7. That the said Thomas Hall vpon the feast day of the Ascension last past when one of the morrice dauncers had leaped \& daunced in the face of the minister standing in his owne doore, did before a great number of 
people revile $\&$ abuse the minister with these reprothfull speaches sc. that the morrice dauncers should dance before his doore $\&$ before his face in spite of him \& in spite of his teeth \& that they would ridd the towne of him; asking him disdainfullie what he was, with many other threatning speeches.

I pray you Master lones after that you haue thus Articled against the said Thomas Hall, take out a Commission to examine witnesses (which I haue many) to proove these Articles: \& vpon your letter sent to me by Ockingham or the Carrier; I will send what fees you write to be due; as also the names of my Commisioners. when I know how many Commissioners are required; then also I will write to you about interragatories; $\&$ other particulars vpon your direction; thus defying your best furtherance in an honest cause; with hartie commendations to you $\&$ my prayers to god for you. I end \& rest

Feb 1, 1620. from New Windsor

Your vnknowne yet loving
Client
lohn Marten vicar
of New Windsor ${ }^{2}$

This petition documents the profound split in English society that preceded the Civil War. Marten represents the new Puritan spirit craving godliness and order and invoking the ancient courts of the church to prosecute the social behaviour of those who, like "the said Thomas" still lived in the festive world of licensed liberty into which he had been born. Thomas Hall takes his job as churchwarden seriously. He raises money in the tried and true manner with plays and morris dancing; he spends the money to repair the church property and even harangues the parishioners to pay the new-fangled twopence fee for pews. Yet to the new vicar his behaviour is blasphemous and his associates reprobates to be censured by the ecclesiastical courts and, possibly, excommunicated.

The work of Mikhail Bakhtin as it has been used by such historians as Natalie Zemon Davis has helped us to understand the complex symbolism represented by festive custom in the early modern period. Yet Bakhtin's argument that carnival was the first step towards freeing European society from the "official culture of the Middle Ages" is hard to apply to England. ${ }^{3}$ What seems to be emerging, particularly from the work of the Records of Early English Drama project, is that until the last quarter of the sixteenth century English festive customs were integral to the official culture. There- 
after, what Leah Marcus calls "old holiday pastimes"4 became tightly entwined with the struggle for the conscience of the kingdom represented by Puritans like John Marten. The coincidence of the rise of Puritanism in England and the breakup of the old social order has produced a phenomenon unlike what happened on the continent. In England, almost all elements of festive custom became pawns in a revolution that changed the character of English society.

The instrument that was used to prosecute those who carried out the old customs first appeared in Visitation Articles in the diocese of York in 1575,

Item that the minister and churchewardens shall not suffer anye lordes of misrule or sommerr Lordes or ladyes or anye disguised persons or others in christmasse or at may gammes or anye minstrels morrie dauncers or others at Ryshebearinges or at any other tymes to come vnreverentle into anye churche or chappell or churchyeard and there daunce or playe anye vnseemelye partes with scoffes ieastes wanton gestures or rybaulde talke namely in the tyme of divine service or of anye sermon. ${ }^{5}$

Such articles were repeated again and again by other bishops and the questions became a standard part of diocesan visits. The struggle was carried out at the local, diocesan or parish level with seemingly little reference to edicts issued at the centre either by the church or by the king himself such as James' famous Declaration Concerning Lawful Sports. The Bishop of Gloucester, for example, in 1622 four years after the promulgation of the James' Declaration which allowed many of the pastimes, included these questions in his Visitation Articles to be asked of every churchwarden in his diocese:

\footnotetext{
28 Whether haue any Lords of misrule, dauncers, players, or any other disguised person, beene suffered to dance or play vpon the Sabbath day, or to enter into the church or chapell, with games or daunces, to the prophaning of Gods house, or into the church-yarde in time of Diuine seruice: and if they haue, what bee the names of such disordered persons. 29 Whether there be any stage-playes, beare-baitings, bul-baitings, or other such vnlawfull and prophane exercises vsed vpon the Sabbath day: and who gaue them Licence. Whether there be any common drinkings in the Church, and who were present at such drinkings: or sports, or any that do sit in the Tauerne, or Alehouse, or streetes vpon Sundayes or Holidayes, in time of morning or euening prayer. ...6
} 
Such interrogations, depending on the spirit in which they were carried out, could have constituted a kind of guerilla war against pastimes that had been approved by the king. The most recent edition of the Records of Early English Drama series, Lancashire, records various examples of such prosecutions. ${ }^{7}$

Yet until about 1575, festive customs had been important elements in the rhythm of the seasons and there is considerable evidence that what Marcus calls "lawless topsy-turvydom" 8 had reinforced rather than challenged the established order by being licensed within it. The customs of both the church and secular society seem to have been carefully controlled to uphold the order that was being inverted.

The most ancient custom that expresses the idea of "licensed liberty" is the practice of electing a choir boy as a mock bishop for part of the Christmas festivites. ${ }^{9}$ The practice was widespread in England from the earliest reference in York in 1221 to the Reformation. The evidence is fragmentary but it appears that in some places the Boy Bishop reigned from St Nicholas Day (6 December) to the Feast of the Holy Innocents (27 December). Evidence from elsewhere suggests that the boy (who according to reforming statutes in York in 1367 and 1390 was to be good looking and have a good voice) was chosen on the Feast of St Nicholas but reigned only on the feast of the Holy Innocents. Evidence for the costuming of the boy as a bishop in full regalia survives from cathedrals, monastic establishments, and schools and colleges. From their foundation in the mid-fifteenth century, for example, Westminster School and Eton and their corresponding colleges (New College, Oxford and King's, Cambridge) had Boy Bishop ceremonies. Although the ceremony did provide opportunities for abuse, its intent was a serious one emphasizing the place of children in the conduct of the service particularly on the day of the feast dedicated to the slaughter of the children. The Boy Bishop and his attendants were expected to conduct themselves with suitable decorum through all the parts of the liturgy that did not demand the services of an ordained priest and the boy was expected to preach a sermon to the community which, of course, included the real bishop.

A secular Christmas figure probably related to the religious customs, the Lord of Misrule, appears in the records of the household of Princess Mary in 1521. The young people who had the care of the young princess appointed one John Thurgood to be the Lord of Misrule for the household over the Christmas season. Among other games and disguising, Thurgood arranged for a man from Windsor to kill a calf "before my lady's grace behind a cloth". ${ }^{10}$ Two years later across the river in Eton, the school appointed one of the servants of the royal household to act as their Lord of Misrule. ${ }^{11}$ At Christmas, 1525 Princess Mary was in Tewkesbury and her new entourage 
wrote to Wolsey to enquire "whither we shall appoynte any lord of mysrule for the said honorable householde/ provide for enterludes Disgysynges or pleyes in the said fest/ or for banket on twelf nyght/". ${ }^{12}$ These Christmas Lords of Misrule seem to have been Masters of Ceremonies or Masters of Revels employed by noble households. The Dean and Chapter of Exeter Cathedral gave the "Abbott of Misrule" of a local magnate called Courtenay a hogshead of wine in $1533^{13}$ and the Gloucester town council twice recorded hiring the "abbott" or Lord of Misrule from the households of Sir Anthony Kingston and Sir Nicholas Arnold in 1550 and $1563 .{ }^{14}$ These men were, presumably, hired to arrange a Christmas party for their clients. The custom survived in the north well into the seventeenth century. The Carlisle town council provided a costume for their Abbot of Misrule in 1610 and ten years later it seems that Willy, the town fool, acted as their abbott. ${ }^{15}$

Equally pervasive were the summer customs that are only now coming to be fully understood as the editors for the Records of Early English Drama project comb through the church records of the sixteenth century. It was the responsibility of the parishioners, led by the churchwardens, to maintain the fabric of the church west of the chancel steps including the roof, the tower, the porch and the churchyard. In most country parishes the necessary money was raised (as Thomas Hall of Windsor had apparently been doing) by a series of parish events including "Hocking" (which survives today in the Sadie Hawkins customs), performing religious plays as well as the ever present folk play of Robin Hood, morris dancing, and other communal activities. These were usually focussed on the midsummer or Whitsun festival when parishes all over the country held Church Ales often termed King Ales or King Plays where home-brew was sold, often a fair was held, minstrells played and May-poles were erected. A profit was made from almost every one of these activities. Some small Berkshire parishes frugally chopped up the may-pole and sold the wood for fire-wood ${ }^{16}$. The festivities were often presided over by a Lord and Lady of the festival sometimes called summer lords and ladies. Sometimes these figures took on the names of Robin Hood and Maid Marion. The social inversion of these occasions was conscious. Evidence survives from the parish of Wing in Buckinghamshire that servants of local gentlemen, especially those of Sir William Dormer, were chosen to preside over the festival. ${ }^{17}$

Shakespeare, in 1611, exploits this custom in the fourth act of Winter's Tale when he portrays Perdita, the lost princess of Sicilia, playing the queen of the country festival in Bohemia. Florizel, her princely suitor, leads her to the role while her adopted father, the Shepherd, urges her to take her responsibilities at the festivities seriously, 
Fie, daughter! when my old wife liv'd, upon

This day she was both pantler, butler, cook,

Both Dame and servant; welcom'd all, serv'd all;

Would sing her song and dance her turn; now here

At the upper end o' th' table, now i' th' middle;

On his shoulder, and his; her face o' fire

With labour, and one thing she took to quench it

She would to each one sip. You are retired,

As if you were a feasted one, and not

The hostess of the meeting: pray you, bid

These unknown friends to 's welcome; for it is

A way to make us better friends, more known.

Come quench your blushes, and present yourself

That which you are, Mistress o' th' Feast. Come on,

And bid us welcome to your sheep-shearing,

As your good flock shall prosper. (IV, iv, 55-69)

At the end of his career, Shakespeare turns to the fast dying customs of his childhood to portray an idyllic pastoral world far from the suspicions of the court. But the idyll was soon to be disallowed. Only a few years after Shakespeare's play William Rice and Dionisia Watkins, two parishioners of Welsh Newton in Herefordshire, were excommunicated for taking the parts of the Lord and Lady of Misrule at the summer festival. ${ }^{18}$

The Puritan spirit which would so briefly dominate English society before it was transported to New England, felt compelled to repress any challenge to its sense of fit and godly behaviour. Through the very immediate instrument of the ecclesiastical courts, the personal lives of countless individuals were disrupted often through the testimony of their neighbours. Reading the court records of this period, one is struck, on the one hand, by the sincerity of many of the Puritans and, on the other, by the opportunism of many others who used the ideological zeal of the godly to settle old scores with neighbours and family members alike. Evangelical fervour and meanspirited pettiness jostle one another in page after page of evidence.

Another case that demonstrates the way in which the inhabitants of small communities were pitted against one another is documented in the court records of the Bishop of Salisbury. In March 1623, Thomas Kent and his daughter Susan were cited before the bishop's court for their behaviour in the parish of Wyly, Wiltshire, on the western edge of Salisbury Plain. ${ }^{19}$ It is clear from the depositions that the incumbent of the parish church, John Lee, had changed the life of the parish with his Puritan principals. Thomas Kent, styled "gentleman", despite the fact that he had been an infrequent church-goer, 
became churchwarden and proceeded to harrass the parson. For example, Lee complained that Kent refused to cut the bread for communion and provided mere sack from the local pub rather than the more refined muscadine although his fellow churchwarden would have been prepared to travel to Salisbury or Warminster to procure the finer wine. Kent's response at being reproached by Lee was to say that "the minister should Doe yt himself if he would" (f 37v). Kent was also loud in his criticism of the length of Lee's sermons "saying that yt were more fit for mens servantes to be at home with their cattle then here" (f 37). But most telling is the testimony of a neighbour, Elizabeth Wadling, against Susan Kent,

... that vppon a sonday in thafternoone within this xij monethes Last/ Mr Lee the parson of wyly being in the church amongst his parishoners perswaded them to come more orderly to church to heare the cathechism aswell thold as the young, whervppon she the said $\backslash$ Susan being present said in this Deponentes hearing that she would not sitt here soe long for said she when eure he (meaning $\mathrm{mr}$ Lee) takes his greene book in hand wee shall haue such a Deale of bibble babble that I am weary to heere yt \& I can then sitt downe in my seat and take a good napp and this deponent being by her \& some others bad her to be quyet and not to talke soe irreuerently of their parson in the churche \& that they were fearfull he did heere her to which she answered I care not $\&$ if he doe for he speaks against vs for our daunsing but now my father will mayntayne yt for the king doth allow of yt farder saying vizt wee had a good parson heere before but now we haue a puritan but said she a plague or a pox in him that euer he did come hither \& I would wee had Kept our old parson for he did neuer dislike with them at any tyme $\&$ she being farder reproved said in this manner vizt theis proud puritans are $\mathrm{vp}$ at the top now but I hope they will haue a tyme to come as fast downe as euer they come vp ... ff $41 \mathrm{v}-42$

Clearly the Kents and their friends were hankering for the older world where dancing and music had been part of the life of the village. However, it is clear, in this situation, from the number of witnesses against them, that Lee had many strong supporters in the parish. Unlike the case in Windsor, here in Wyly the upholders of the old ways were on the defensive not the Puritan parson.

The custom of Christmas lords became a weapon in the hands of northern Puritans against recusants. About 1616, a charge of recusancy was brought against Lord William Howard of Thornthwaite and part of the charge was that

... ye tenantes and servantes of ye lord William assisted with others of ye parish did erect a christemas lord, and resorting to ye church, did most 
grossely disturb ye minister in tyme of prayer ... these christemas misrule men, drunke to ye minister readinge an homilie in ye pulpitt, others stept into ye pulpitt, and exhorted ye parishioners to an offeringe for mayntenance of there sport, ye minister contynuinge still his service, others of ye lord william owne servantes came in savage manner disguised into ye churche, in ye tyme of prayer, others with shootinge of gunnes, others with flagges and banners borne entered ye churche, others sported them selves in the churche with pies, and puddinges, vsinge them as bowles in ye churche allies ... all there in the tyme of diuine service ${ }^{20}$

Customs that stemmed from the licensed liberty of Catholic ceremony become part of the arsenal to be used against the adherents of the old religion in a district famous for its religious stubborness.

Licensed liberty as it was known in England before 1575 could only flourish in stable society where the accustomed and often repressive norms were accepted. When a whole society had consented to a normative pattern, that pattern could be inverted and burlesqued at festival time without the system itself being threatened. But by the early seventeenth century there was no societal norm in England. The insecurity of the dominant Puritan faction can be seen again and again in their fear of the expressions of the ancient festive customs. For them licensed liberty was mere license, and as this extract from a sermon preached before Sir Robert Foster, Justice of Assize in Exeter in 1642 shows, a metaphor for inadequate rule,

... A pittifull thing it was, that those which should curbe and restraine others, should be sonnes of Belial, lawlesse, yoaklesse themselves, That those which should set bounds to others, will keep no limits themselves, that those which should have beene the Governours of the people, should be little better that Christmasse-Lords, Lords of mis-rule, and disorder; $\ldots{ }^{21}$

The narrowness of the Puritan vision was proved by their inability to survive in power more than a few generations. But those few generations marked a profound change in English society. Many of the customs and ceremonies of the medieval past survived in the countryside beyond the reign of Elizabeth. Very few of them were left by the time of the Restoration. When some were revived in the eighteenth century, they were a product of antiquarian zeal, a conscious return to a lost past. The society that had the confidence to license misrule did not survive the actions of the godly. 


\section{Notes}

1. According to Hazlitt (Faiths and Folklore of the British Isles, revised edition 1905 vol. II, pp.490-1) pigeon-holes "probably resembled a variety of bagatelle called bridge". The game is frequently associated with bowling and may have demanded skill similar to that needed for darts. In the seventeenth century it was associated with Witsun.

2. Oxfordshire County R.O. MS Oxon. Archd. Papers, Oxon. c.174, ff 199-199v.

3. Mikhail Bakhtin, Rabelais and his World, trans. Helene Iswolsky, Indiana University Press, 1984, p. 274.

4. Leah S. Marcus, The Politics of Mirth, Chicago, 1986, uses the phrase as part of her subtitle "Jonson, Herrick, Milton, Marvell and the Defense of old holiday pastimes."

5. Alexandra F. Johnston and Margaret Rogerson, eds., Records of Early English Drama: York, Toronto, 1979, p.358.

6. Audrey Douglas and Peter Greenfield, eds. Records of Early English Drama: Cumberland, Westmorland and Gloucestershire. Toronto, 1986. p. 346.

7. David George, ed., Records of Early English Drama: Lancashire Toronto, 1992. The collection of the Somerset records being edited by James Stokes for the REED series is even richer in the number and complexity of the prosecutions.

8. Marcus, p. 7.

9. Evidence for Boy Bishop activities appear in many collections in the Records of Early English Drama series (University of Toronto Press 1979-), particularly those related to monastic establishments. See also E.K.Chambers, The Medieval Stage, London 1903, vol. I, pp.336-71 and W.C. Meller, The Boy Bishop, London, 1923, pp. 3-18.

10. Public Record office E $36 / 216$ endpapers.

11. Eton College Records, Act Book I, 1523-4.

12. Audrey Douglas and Peter Greenfield, eds., Records of Early English Drama: Cumberland, Westmorland and Gloucestershire, Toronto, 1986, pp.296 and 299.

13. John Wasson, ed., Records of Early English Drama: Devon, Toronto, 1987, p.133.

14. REED:CWG, pp. 296 and 299.

15. ibid. pp. 71 and 24.

16. See, for example, the churchwardens' accounts of St Denys, Stanford-in-the-vale (Berkshire Record Office D/P 118 5/1) for the years 1611-2, 1613-4 and 1619-20.

17. Buckinghamshire Record Office, PR 234/5/1, ff. $174 \mathrm{v}$ and $67 \mathrm{v}-81 \mathrm{v}$.

18. David Klausner, ed., Records of Early English Drama: Herefordshire and Worcestershire, Toronto, 1990, pp. 173-4.

19. Wiltshire Record Office, Bishop's Act Books, Office, D1/39/2/11, ff 35v-43.

20. REED:CWG, p. 218.

21. REED:Devon, p. 205. 